\title{
PENGARUH PENDAPATAN ASLI DAERAH, DANA ALOKASI UMUM, DANA ALOKASI KHUSUS DAN DANA OTONOMI KHUSUS TERHADAP BELANJA DAERAH KABUPATEN/KOTA DI PROVINSI ACEH
}

\author{
Muhammad Iqbal' ${ }^{1}$, Tarmizi Abbas ${ }^{2 *}$, Ratna $^{3}$ \\ ${ }^{1}$ Mahasiswa Program Pascasarjana Ilmu Manajemen, Universitas Malikussaleh \\ ${ }^{23}$ Dosen Program Pascasarjana Ilmu Manajemen, Universitas Malikussaleh \\ Email : iqbalputra1010@gmail.com ${ }^{1}$, tamiziabbas@unimal.ac.id ${ }^{2}$, ratna@unimal.ac.id ${ }^{3}$
}

\begin{abstract}
This study aims to examine the effect of Own Source Revenues, General Allocation Funds, Special Allocation Funds, and Special Autonomy Funds on Regional Expenditures. This study uses a combination of cross section data with time series in 23 regencies/cities in Aceh Province during 2010-2017, obtained from the Budget Realization Report (LRA) issued by the Directorate General of Regional Financial Management of the Ministry of Finance (DJPK Ministry of Finance). The data analysis method used is Panel Data Regression with the help of Eviews 10. The results of this study prove that Own Source Revenues, General Allocation Funds, Special Allocation Funds, and Special Autonomy Funds have a positive and significant effect on regional expenditures. The magnitude of the effect of Own Source Revenues, General Allocation Funds, Special Allocation Funds, and Special Autonomy Funds on regional expenditure is $94.22 \%$ and the remaining $5.78 \%$ is influenced by other variables outside this research model. It is recommended to local governments to use Own Source Revenues, General Allocation Funds, Special Allocation Funds, and Special Autonomy Funds effectively and efficiently so that Regional Expenditures can be increased, and the Special Autonomy Fund should be used in the interests of the general public so as to reduce poverty and the people of Aceh become more prosperous.
\end{abstract}

Keywords: Own Source Revenues, General Allocation Funds, Special Allocation Funds, Special Autonomy Funds, Regional expenditures.

\section{PENDAHULUAN}

Otonomi daerah yang telah berlaku di Indonesia didasarkan kepada UU Nomor 32 tahun 2004 yang merupakan revisi dari UU Nomor 22 tahun 1999. Dalam UU menjelaskan bahwa pemerintah memisahkan fungsi eksekutif dan legislatif. Hal tersebut menunjukkan bahwa daerah diberi kewenangan luas untuk mengatur dan mengurus daerahnya sendiri. Pemerintah daerah memiliki hak dan kewenangan yang luas untuk menggunakan sumber-sumber keuangan yang dimilikinya, sesuai dengan kebutuhan pada masyarakat di daerahnya. Undang-Undang tersebut juga menegaskan bahwa daerah memiliki kewenangan untuk menentukan alokasi sumber daya ke dalam belanja-belanja daerah.

Belanja daerah di Indonesia sesungguhnya diatur oleh Undang-Undang dan peraturan resmi. Berdasarkan Undang-Undang Republik Indonesia No 33 Tahun 2004, belanja daerah diartikan sebagai semua kewajiban daerah yang diakui sebagai pengurangan nilai kekayaan bersih dalam periode tahun anggaran yang bersangkutan. Sementara itu, Peraturan Kementrian Dalam Negeri No 59 Tahun 2007 tentang Pedoman Pengelolaan Keuangan Daerah menyatakan bahwa belanja daerah merupakan kewajiban pemerintah daerah yang diakui sebagai pengurangan kekayaan bersih.

Beberapa ahli juga telah berpendapat mengenai belanja daerah. Menurut Halim (2007), belanja daerah merupakan pengeluaran yang dilakukan oleh pemerintah daerah untuk melaksanakan wewenang dan tanggung jawab kepada masyarakat dan pemerintahan di atasnya. Sementara itu, Erlina et al. (2012) berpendapat bahwa belanja daerah adalah suatu rencana keuangan yang disusun untuk satu periode mendatang yang berisi tentang pengeluran yang menggambarkan strategi pemerintah dalam mengalokasikan sumber daya yang terbatas untuk pembangunan daerah yang juga berfungsi sebagai alat pengendalian dan instrument politik. 
Berdasarkan Undang-Undang Republik Indonesia No 33 Tahun 2004, belanja daerah sendiri diklasifikasikan menjadi dua jenis yaitu belanja tidak langsung dan belanja langsung. Belanja tidak langsung terdiri dari belanja pegawai, belanja hibah, belanja bantuan sosial, belanja bagi hasil kepada Provinsi/Kabupaten/Kota dan Pemerintah Desa, belanja Bantuan Keuangan kepada Provinsi/Kabupaten/Kota dan Pemerintahan Desa, dan Belanja tidak terduga, sedangkan belanja langsung terdiri dari belanja pegawai, belanja barang dan jasa, dan belanja modal.

Belanja daerah juga menjadi aspek yang penting dalam otonomi daerah. Daerah otonom yang baik merupakan daerah yang mampu melakukan investasi yang tepat dengan belanja daerah yang dianggarkannya (Koswara, 2001). Sementara itu, Afrizawati (2012) berpendapat bahwa belanja daerah merupakan pengeluaran regional yang digunakan untuk mendanai penyelenggaraan kegiatan pemerintahan yang menjadi tanggung jawab pemerintah, serta urusan yang penyelesaiannya dalam aspek tertentu yang bisa dijalankan bersama-sama antara pemerintah sentral dengan pemerintah regional ataupun antara pemerintah regional. Ini menunjukkan bahwa belanja daerah menjadi aspek yang penting bagi suatu pemerintah daerah, termaksud daerah Provinsi Aceh.

Provinsi Aceh merupakan salah satu daerah yang diberikan otonomi khusus oleh pemerintah pusat melalui UU No.18/2001 tentang Otonomi Khusus Bagi Provinsi Daerah Istimewa Aceh Sebagai Provinsi Nanggroe Aceh Darussalam. Pemberian otonomi khusus tersebut diharapkan dapat meningkatkan laju pertumbuhan dan pembangunan ekonomi Aceh ke arah yang lebih baik, dumana selama ini Aceh yang jauh tertinggal dibandingkan kemajuan ekonomi provinsi lain di Indonesia, yang pada akhirnya pencapaian tersebut dapat memberikan kesejahteraan bagi masyarakat Aceh.

Beberapa studi terdahulu telah membahas mengenai belanja daerah di Provinsi Aceh. Kajian yang dilakukan oleh Martunis et al. (2014) menemukan bahwa belanja daerah pada Kabupaten/Kota di Provinsi Aceh sebesar Rp 48 Trilliun Rupiah untuk periode 2009-2012. Sementara itu, Mulyati \& Yusriadi (2017) menemukan bahwa belanja daerah sebesar Rp 868 Miliyar untuk periode 2013-2015.

Selanjutnya Syamni \& Ichsan (2018), memberikan implikasi bahwa penurunan belanja daerah di Provinsi Aceh menyebabkan Aceh memiliki tingkat pertumbuhan ekonomi yang melambat.Hal tersebut membuat penulis tertarik untuk mengkaji belanja daerah kabupaten/kota di Provinsi Aceh, serta faktor-faktor yang mempengaruhinya.

Beberapa studi sebelumnya telah membuktikan bahwa Pendapatan Asli Daerah (PAD), Dana Alokasi Umum (DAU), Dana Alokasi Khusus (DAK), dan OTSUS menjadi faktor yang mampu mendorong peningkatan belanja daerah secara signifikan (Magowan, 2013; Martunis et al., 2014; Mulyati \& Yusriadi, 2017; Syamni \& Ichsan, 2018; Rasyid, 2018; Ferdiansyah et al., 2018; Anwar et al., 2018; Jikwa \& Salle, 2017). Akan tetapi, beberapa studi lainnya mendokumentasikan hasil yang kontradiktif, dimana faktor-faktor tersebut tidak berpengaruh signifikan terhadap belanja daerah (Putra \& Dwirandra, 2015; Ernayani, 2017; Rasyid, 2018; Indiransyah, 2017). Ini menunjukkan bahwa pengaruh PAD, DAU, DAK dan OTSUS terhadap belanja daerah masih berubah-ubah dari waktu ke waktu sehingga penulis terdorong untuk menganalisisnya pada Kabupaten/Kota di Provinsi Aceh.

\section{LITERATUR REVIEW DAN HIPOTESTS}

\section{Pengaruh PAD terhadap Belanja Daerah}

PAD dapat diartikan sebagai sumber dana bagi Pemerintah daerah dala membangun infrastruktur dan kemakmuran masyarakat daerah. PAD bersumber dari hasil pajak daerah, hasil retribusi daerah, hasil pengelolaan kekayaan daerah yang dipisahkan dan lain-lain PAD yang sah. Untuk itu, dalam masa desentralisasi seperti ini, pemerintah daerah dituntut untuk bisa mengembangkan dan meningkatkan PADnya masing-masing dengan memaksimalkan sumberdaya yang dimiliki supaya bisa membiayai segala kegiatan penciptaan infrastruktur atau sarana prasarana daerah melalui alokasi belanja daera pada APBD (Wandira, 2013). Peningkatan PAD juga mendorong naiknya pengalokasikan pada belanja daerah kabupaten/kota (Simanjuntak et al., 2013).

Beberapa riset sebelumnya juga telah menemukan bahwa PAD berpengaruh positif terhadap belanja daerah. Mawarini et al. (2013) menemukan bahwa PAD berpengaruh positif dan signifikan terhadap belanja daerah pada kabupaten/kota di provinsi Aceh. Temuan tersebut didukung oleh penelitian Syamni \& Ichsan (2018) menemukan bahwa PAD dapat meningkatkan belanja daerah Kabupaten/Kota di Provinisi Aceh. Magowan (2013) juga mendokumentasikan hasil yang sama di Provinsi Sulawesi Utara. 
Ini menunjukkan bahwa PAD memberikan pengaruh positif dan signifikan terhadap belanja daerah, yang artinya peningkatan PAD akan berdampak terhadap peningkatan belanja Daerah.

\section{Pengaruh DAU terhadap Belanja Daerah}

Dana Alokasi Umum (DAU) dapat diartikan sebagai dana yang dari APBN yang dialokasikan ke daerah demi pemerataan kemampuan keuangan antar daerah untuk membiayai kebutuhan daerah dalam rangka pelaksanaan desentralisasi. DAU ditentukan dari kecil besarnya fiscal gap daerah, dimana fiscal gap adalah selisih kebutuhan daerah dengan potensi daerah (Halim, 2007). DAU digunakan untuk menutup celah yang terjadi karena kebutuhan daerah melebihi dari potensi penerimaan daerah yang ada (Ferdiansyah et al., 2018). Pemerintah daerah dapat bebas dalam menggunakan dana ini untuk meningkatkan pelayanan ke arah yang lebih baik kepada masyarakat (Hairiyah et al., 2017).

Beberapa studi sebelumnya juga telah menemukan bahwa DAU berpengaruh positif dan signifikan terhadap belanja daerah. Rasyid (2018) menemukan bahwa DAU memiliki pengaruh positif dan signifikan terhadap belanja daerah Kabupaten/Kota di Sulawesi Tengah. Ernaya (2017) menemukan bahwa semakin tinggi DAU maka belanja daerah akan semakin meningkat di Kabupaten/Kota Provinsi Kalimantan Timur. Putra \& Dwirandra (2018) juga mendokumentasikan bahwa peningkatan belanja daerah dipengaruhi oleh peningkatan DAU di Provinsi Bali.

\section{Pengaruh DAK terhadap Belanja Daerah}

Dana Alokasi Khusus adalah alokasi dari Anggaran Pendapatan dan Belanja Negara kepada daerah tertentu dengan tujuan untuk mendanai kegiatan khusus yang merupakan urusan Pemerintahan Daerah dan sesuai dengan prioritas nasional. Sesuai dengan UU Nomor 33 Tahun 2004, yang dimaksud dengan kebutuhan khusus adalah kebutuhan yang tidak dapat diperkirakan dengan menggunakan rumus alokasi umum, dalam pengertian kebutuhan yang tidak sama dengan kebutuhan daerah lain. Di beberapa daerah peran DAK sangat nyata dikarenakan alokasi belanja daerah lebih dominan bersumber dari DAK dibandingkan dengan PAD (Nailufar \& Safitrayati, 2019).

Beberapa studi sebelumnya telah membuktikan bahwa DAK menjadi elemen yang dapat meningkatkan belanja daerah secara signifikan. Kajian yang dilakukan oleh Syamni \& Ichsan (2018) di Kabupaten/Kota yang terdapat di Provinsi Aceh mendokumentasikan bahwa DAK berpengaruh positif dan signifikan terhadap belanja daerah. Ferdiansyah et al. (2018) menemukan bahwa menemukan bahwa peningkatan DAK mempengaruhi peningkatan belanja daerah di kabupaten/kota Provinsi Kalimantan Timur.

\section{Pengaruh OTSUS terhadap Belanja Daerah}

OTSUS merupakan suatu dana yang alokasinya ditujukan untuk membiayai operasional otonomi khusus suatu daerah. Dana otonomi khusus hanya diterima oleh daerah tertentu di Indonesia, yakni Aceh, Papua dan Papua Barat. Penerimaan dana otonomi khusus untuk daerah Aceh diatur dalam Undang-Undang Nomor 11 Tahun 2006 tentang Pemerintah Aceh. Dana otonomi khusus merupakan penerimaan Pemerintah Aceh yang ditujukan untuk membiayai pembangunan terutama pembangunan dan pemeliharaan infrastruktur, pemberdayaan ekonomi rakyat, pengentasan kemiskinan, serta pendanaan pendidikan, sosial,dan kesehatan.

Khusus untuk Provinsi Aceh, Papua, dan Papua Barat, pemerintah pusat memberikan dana lainnya berupa dana otonomi khusus yang digunakan untuk pengeluaran daerah. Pengeluaran daerah merupakan pengeluaran dana, baik yang bersumber pendapatan asli daerah maupun dana perimbangan yang akan mengurangi pendapatan daerah. Dana otsus diberikan untuk meningkatkan kesejahteraan dan kemajuan masyarakat dalam mengejar ketertinggalan dari daerah-daerah lainnya di Indonesia. Pemberian dana otsus pada suatu daerah khususnya daerah Aceh merupakan kebebasan bagi rakyat untuk mengatur rumah tangga pemerintahnya sendiri. Kewenangan yang dilakukan dalam hal mendengar aspirasi masyarakat, menetapkan, melaksanakan, mengawasi, dan mengevaluasi kebijakan, termasuk pengaturan dana untuk belanja modal. Hal ini memberikan banyak pilihan pemerintah Aceh dalam membiayai pembangunan. Studi-studi sebelumnya juga mendokumentasikan bahwa OTSUS menjadi elemen penting yang mempengaruhi belanja daerah secara signifikan (Anwar et al., 2018; Nufus \& Asmara, 2017; Jikwa \& Salle, 2017). 
Berdasarkan uraian di atas, maka hipotesis yang dapat dibangun dalam penelitian ini disajikan pada tabel di bawah ini:

$\mathrm{H}_{1}$ : Pendapatan Asli Daerah (PAD) berpengaruh signifikan terhadap Belanja Daerah Kabupaten/Kota di Provinsi Aceh

$\mathrm{H}_{2}$ : Dana Alokasi Umum (DAU) berpengaruh signifikan terhadap Belanja Daerah Kabupaten/Kota di Provinsi Aceh

$\mathrm{H}_{3}$ : Dana Alokasi Khusus (DAK) berpengaruh signifikan terhadap Belanja Daerah Kabupaten/Kota di Provinsi Aceh

$\mathrm{H}_{4} \quad$ : Dana Otonomi Khusus (OTSUS) berpengaruh signifikan terhadap Belanja Daerah Kabupaten/Kota di Provinsi Aceh

\section{METODE}

Penelitian ini dilakukan pada seluruh Kabupaten/Kota di Provinsi Aceh selama periode 2010-2017 yaitu sebanyak 23 Kabupaten/Kota. Data diperoleh dengan mengakses situs resmi Direktorat Jendral Perimbangan Keuangan (DJPK) yang diakses memalui situs resemi yaitu www.djpk.kemenkeu.go.id.

Jenis data yang digunakan dalam penelitian ini adalah data panel. Sugiyono (2016) mengatakan bahwa data Panel (pooled data) adalah data gabungan antara time series data dengan cross section data. Dikatakan data gabungan karena data ini terdiri atas beberapa objek dalam beberapa periode waktu. Periode dalam penelitian ini selama selama 2010-2017 (time series) dan objek sebanyak 23 Kabupaten/Kota (Cross Section) sehingga banyaknya observasi dalam penelitian ini adalah 184 observasi.

Penelitian ini secara umum menggunakan 1 variabel terikat dan 4 variabel bebas. Variabel terikat dalam penelitian ini adalah belanja daerah Kab/Kota di Provinsi Aceh yang diukur dalam rupiah. Sementara itu, variabel bebas dalam penelitian ini terdiri dari PAD, DAU, DAK dan OTSUS pada Kabupaten/Kota di Provinsi Aceh yang diukur dengan satuan Rupiah. Adapun persamaan statistik yang akan diuji dalam penelitian ini adalah sebagai berikut:

$$
\operatorname{LnBD}_{i t}=\beta_{0}+\beta 1 \operatorname{LnPAD}_{\text {it }}+\beta_{2} \operatorname{LnDAU}_{\text {it }}+\beta_{3} \operatorname{LnDAK}_{\mathrm{it}}+\beta_{4} \operatorname{LnOTSUS}_{\mathrm{it}}+\varepsilon_{\mathrm{it}}
$$

Keterangan:

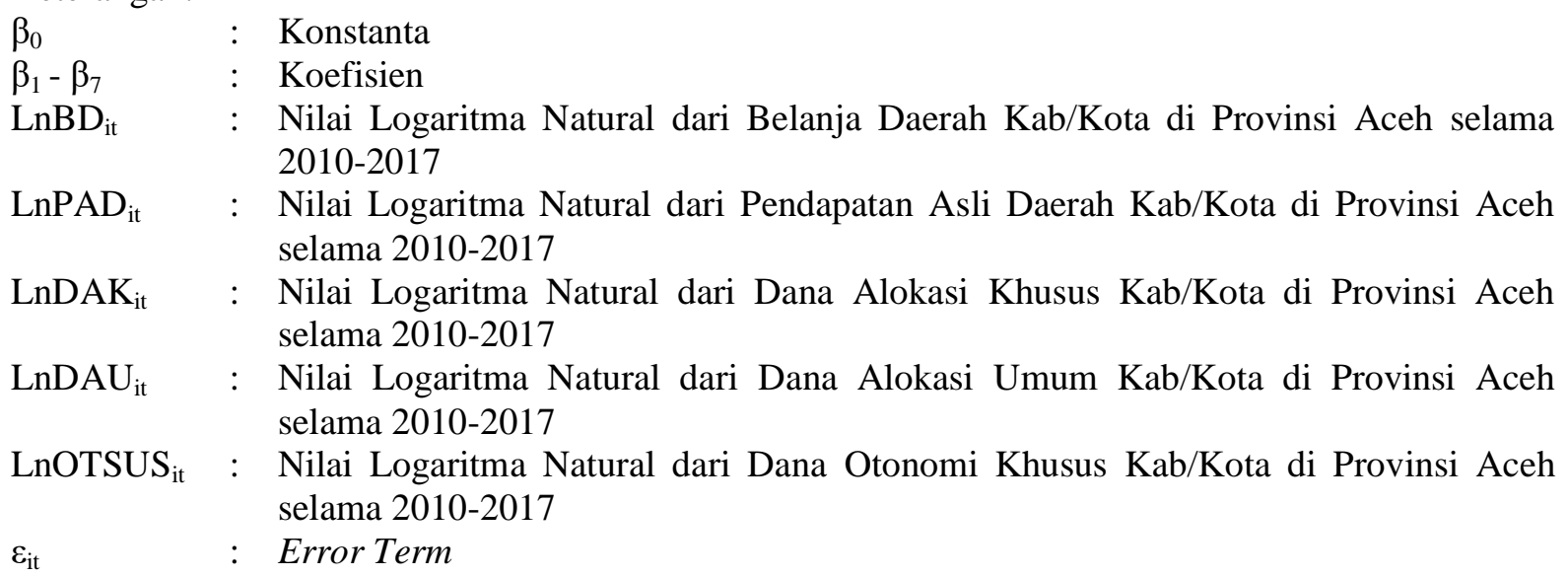

\section{HASIL PENELITIAN DAN PEMBAHASAN Analisis Deskriptif Statistik}

Pada analisis statistik deskriptif, akan terlihat bagaimana nilai rata-rata, nilai standar deviasi, nilai maksimum dan nilai minimum dari data yang digunakan dalam penelitian ini. Adapun hasil analisis deskriptif dalam penelitian ini adalah sebagai berikut:

\section{Tabel 1}

\section{Analisis Deskriptif Statistik (dalam Jutaan Rupiah}

Mean SD Max Mi




\begin{tabular}{cccccc}
\hline BD & 850,000 & 457,000 & $2,710,000$ & 265,000 \\
PAD & 79,800 & 114,000 & 947,000 & 3,360 \\
DAU & 454,000 & 160,000 & 872,000 & 163,000 \\
DAK & 86,500 & 82,600 & 397,000 & 16,800 \\
OTSUS & 102,000 & 104,000 & 643,000 & 450 \\
\hline
\end{tabular}

Sumber : : Data Diolah, 2019

Keterangan : Mean adalah nilai rata-rata. SD adalah standar deviasi. Max adalah nilai tertinggi. Min adalah nilai terendah. Obs adalah jumlah pengamatan. BD adalah Belanja Daerah. PAD adalah Pendapatan Asli Daerah. DAU adalah Dana Alokasi Umum. OTSUS adalah Dana Alokasi Khusus.

Berdasarkan Tabel 5.1 di atas, terlihat bahwa belanja daerahmemiliki rata-rata sebesar Rp 850.000.000.000 dengan standar deviasinya sebesar Rp 457.000.000.000. Hasil ini menunjukkan bahwa nilai rata-rata lebih tinggi dibandingkan nilai standar deviasinya yang menunjukkan bahwa data belanja daerah dalam penelitian ini berfluktuasi rendah dan rata-rata telah menyebar dengan baik. Nilai tertinggi belanja daerah sebesar Rp 2.710.000.000.000 dan nilai terendahnya sebesar Rp 265.000.000.000 dengan jumlah observasi sebanyak 184 observasi.

Selanjutnya, PAD memiliki nilai rata-rata sebesar Rp 79.800.000.000 dengan standar deviasi sebesar Rp 114.000.000.000. Hasil ini menunjukkan bahwa PAD memiliki nilai rata-rata di bawah nilai standar deviasinya yang artinya data PAD dalam penelitian ini memiliki fluktuasi yang tergolong tinggi yang menandakan bahwa PAD dalam kasus ini belum terdistribusi secara merata. Sementara itu, nilai tertinggi PAD sebesar Rp 947.000.000.000 dan nilai terendahnya sebesar Rp 3.360.000.000 untuk 184 observasi.

Nilai rata-rata DAU dalam penelitian ini sebesar Rp 454.000.000.000 dengan standar deviasi sebesar Rp 160.000.000.000. Hasil ini menunjukkan bahwa DAU memiliki nilai rata-rata di atas nilai standar deviasinya yang artinya data DAU dalam penelitian ini memiliki fluktuasi yang tergolong rendah, yang menandakan bahwa distribusi data DAU telah merata. Sementara itu, nilai tertinggi DAU sebesar Rp 872.000.000.000 dan nilai terendahnya sebesar Rp 163.000.000.000 untuk 184 observasi.

Selanjutnya, DAK memiliki nilai rata-rata sebesar Rp 86.500.000.000 dengan standar deviasi sebesar Rp 82.600.000.000. Hasil ini menunjukkan bahwa DAK memiliki nilai rata-rata di atas nilai standar deviasinya yang artinya data DAK dalam penelitian ini memiliki fluktuasi yang tergolong rendah, yang menandakan bahwa distribusi data DAK telah merata. Sementara itu, nilai tertinggi DAK sebesar Rp 397.000.000.000 dan nilai terendahnya sebesar Rp 16.800.000.000 untuk 184 observasi.

OTSUS memiliki rata-rata sebesar Rp 102,000,000,000 dengan standar deviasinya sebesar Rp $104,000,000,000$, dimana nilai rata-rata berada di bawah standar deviasi yang menunjukkan bahwa fluktuasi OTSUS dalam penelitian ini tergolong tinggi. Nilai tertinggi OTSUS dalam penelitian ini sebesar Rp 643,000,000,000 dan nilai terendahnya sebesar Rp 450,000,000.

\section{Analisis Korelasi}

Analisis korelasi merupakan tahapan pengujian untuk melihat hubungan (korelasi) dari setiap variabel yang digunakan dalam penelitian ini. Adapun hasil analisis korelasi dalam penelitian ini dapat dilihat sebagai berikut:

Tabel 2

Analisis Korelasi

\begin{tabular}{|c|c|c|c|c|}
\hline & LNBD & LNPAD & LNDAU & LNDAK \\
\hline LNBD & 1.0000 & & & \\
\hline LNPAD & $0.7811 * * *$ & 1.0000 & & \\
\hline LNDAU & $0.9104 * * *$ & $0.7857 * * *$ & 1.0000 & \\
\hline
\end{tabular}




\begin{tabular}{|c|c|c|c|c|c|c|}
\hline LNDAK & $0.7936 * * *$ & $0.5448 * * *$ & $0.6283^{* * *}$ & 1.0000 & & \\
\hline LNOTSUS & $0.7380 * * *$ & $0.5040 * * *$ & $0.6044 * * *$ & $0.5992 * * *$ & 1.0000 & \\
\hline Sumber & $\mathrm{Da}$ & ta Diolah, 20 & & & & \\
\hline $\begin{array}{l}\text { Keterangan } \\
\text { logaritma na }\end{array}$ & $* *$ & ${ }^{*}, * *, * \operatorname{sign}$ & ifikan pada & level $1 \%, 5 \%$ & an $10 \%$. & LNBD adalah nilai logaritma natural dari belanja daerah. LNPAD adalah nilai \\
\hline
\end{tabular}

Berdasarkan Tabel 2 di atas, ditemukan bahwa PAD, DAU, DAK dan OTSUS berkorelasi positif dengan belanja daerah masing-masing sebesar $0.7811 ; 0.9104 ; 0.7936 ; 0.7380$ dan nilai tersebut signifikan pada level $1 \%$. Untuk hubungan antar variabel bebas, DAU, DAK dam OTSUS berkorelasi positif dengan PAD masing-masing sebesar $0.7857 ; 0.5448 ; 0.5040$ dan nilai tersebut signifikan pada level 1\%. DAK dan OTSUS berkorelasi positif dengan DAU masing-masing sebesar sebesar $0.6283 ; 0.6044$ dan signifikan pada level 1\%, OTSUS berkorelasi positif dengan DAK sebesar 0.5992 dan signifikan pada level $1 \%$.

\section{Teknik Pemilihan Model}

Agar model yang digunakan baik dan sesuai, maka diperlukan penaksiran model. Terdapat tiga model di dalam regresi data panel yaitu Common Effect Model (CEM) atau Pooled Least Square, Fixed Effect Model (FEM) dan Random Effect Model (REM). Untuk menentukan model terbaik dan yang sesuai dengan penelitian ini, maka uji yang dilakukan yaitu Uji Chow dan Uji Hausman. Uji Chow dilakukan untuk membandingkan model CEM dan FEM sedangkan Uji Hausman dilakukan untuk membandingkan FEM dan REM.

\section{Tabel 3}

Uji Chow

\begin{tabular}{lrrc}
\hline \multicolumn{1}{c}{ Effects Test } & \multicolumn{1}{c}{ Statistic } & \multicolumn{1}{c}{ d.f. } & Prob. \\
\hline Cross-section F & 6.012111 & $(22,157)$ & 0.0000 \\
Cross-section Chi-square & 112.442847 & 22 & 0.0000 \\
\hline
\end{tabular}

Sumber : Data Diolah, 2019

Berdasarkan Tabel 3 di atas, ditemukan bahwa nilai probabilitas pada baris Chi Square sebesar 0.0000, dimana nilai tersebut di bawah nilai toleransi kesalahan dalam penelitian ini (0.05). Dengan kata lain, Uji Chow memilih FEM sebagai model yang tepat, sehingga dilanjutkan ke Uji Hausman.

\section{Tabel 4}

Uji LM

\begin{tabular}{lccc}
\hline \multicolumn{1}{c}{ Test Summary } & $\begin{array}{c}\text { Chi-Sq. } \\
\text { Statistic }\end{array}$ & Chi-Sq. d.f. & Prob \\
\hline Cross-section random & 3.818847 & 4 & 0.4311 \\
\hline Sumber : Data Diolah, 2019 & & &
\end{tabular}

Berdasarkan Tabel 4 di atas, ditemukan bahwa nilai proabilitas sebesar 0.4311, dimana nilai tersebut berada di atas nilai toleransi kesalahan dalam penelitian ini (0.05). Dengan kata lain, Uji Chow memilih REM sebagai model yang tepat, sehingga Uji Asumsi Klasik, Estimasi Regresi dan Pengujian Hipotesis dilakukan dengan Random Effect Model. Dikarenakan model yang dipilih adalah REM, maka pengujian asumsi klasik tidak diperlukan (Gujarati \& Porter, 2012).

\section{Estimasi Regresi Linear Berganda}

Hasil pemilihan model menunjukkan bahwa model yang tepat untuk diestimasikan dalam penelitian ini adalah Random Effect Model. Adapun hasil regresi secara Random Effect Model (REM) dapat dilihat pada Tabel 8 di bawah ini:

\section{Tabel 8}

Estimasi Regresi dengan Random Effect Model

\begin{tabular}{ccr}
\hline Variabel Bebas & Koefisien & \multicolumn{1}{c}{$\mathrm{t}_{\text {hitung }}$} \\
\hline C & -0.9095 & -0.8644 \\
LNPAD & 0.0372 & $2.6571 * * *$
\end{tabular}




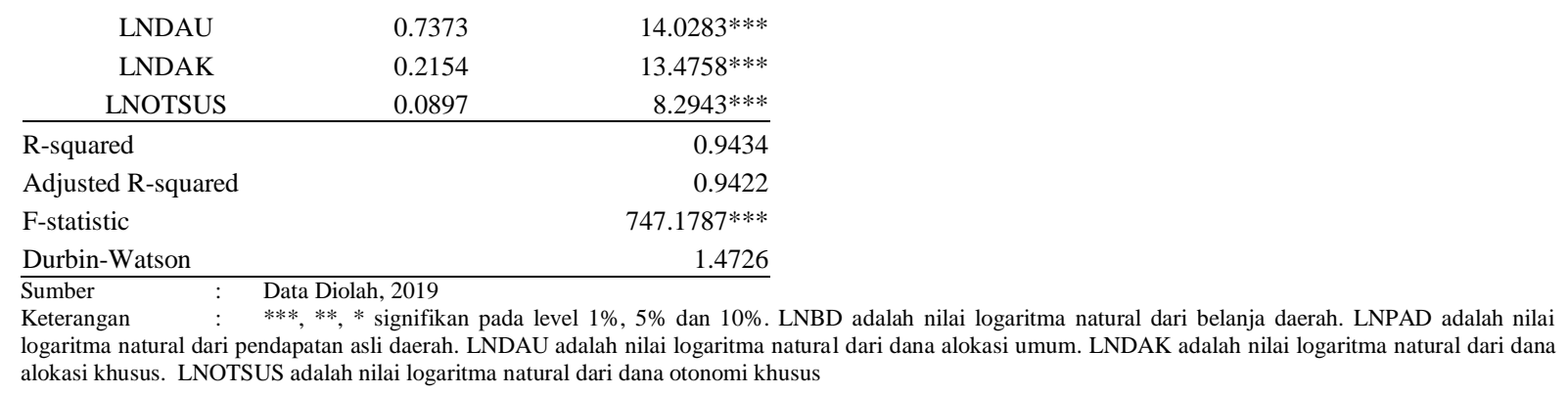

Berdasarkan Tabel 8 di atas, maka persamaan regresi yang dapat disusun adalah sebagai berikut:

$\mathrm{LNBD}=$

$$
-0.9095+0.0372 \mathrm{LNPAD}+0.7373 \mathrm{LNDAU}+0.2154 \mathrm{LNDAK}+0.0897 \mathrm{LNOTSUS}
$$

Berdasarkan persamaan di atas, nilai konstanta sebesar -0.9095, artinya jika PAD, DAU, DAK dan OTSUS bernilai 0, maka Belanja daerah akan tetap konstan sebesar -0.9095. Kemudian, nilai koefisien PAD sebesar 0.0372 yang artinya ketika PAD naik $1 \%$ maka belanja daerah akan meningkat sebesar 0.0372 . Nilai tersebut juga tergolong signifikan pada $5 \%$ dengan $t_{\text {hitung }}$ sebesar 2.6571 yang meunjukkan bahwa PAD berpengaruh positif dan signifikan terhadap belanja daerah, sehingga $\mathrm{H}_{1}$ diterima.

Selanjutnya, nilai koefisien DAU sebesar 0.7373 yang menunjukkan bahwa ketika DAU naik $1 \%$ maka belanja daerah akan bertambah sebesar 0.7373 . Nilai tersebut juga tergolong signifikan pada level $1 \%$ dengan $t_{\text {hitung }}$ sebesar 14.0283, yang artinya DAU berpengaruh positif dan signifikan terhadap belanja daerah, sehingga $\mathrm{H}_{2}$ diterima. Kemudian, DAK memiliki nilai koefisien sebesar 0.2154 , yang artinya ketika DAK naik $1 \%$ maka belanja daerah akan meningkat sebesar 0.2154 . Nilai tersebut juga tergolong signifikan pada level $1 \%$ dengan $t_{\text {hitung }}$ sebesar 13.4758 yang artinya DAK berpengaruh positif dan signifikan terhadap belanja daerah, sehingga $\mathrm{H}_{3}$ diterima.

Adapun OTSUS memiliki nilai keofisien sebesar 0.0897. Hal ini menunjukkan bahwa ketika OTSUS naik $1 \%$, maka belanja daerah akan bertambah sebesar 0.0897 . Selanjutnya nilai $t_{\text {hitung }}$ untuk koefisien OTSUS sebesar 8.2943, dimana nilai tersebut tergolong signifikan di level 1\%, Dengan kata lain, OTSUS berpengaruh positif dan signifikan terhadap belanja daerah, sehingga menerima $\mathrm{H}_{4}$.

\section{Koefisien Determinasi}

Pada Tabel 8, nilai koefisien determinasi (Adjusted R Square) sebesar 0.9422, artinya PAD, DAU, DAK dan OTSUS mempu memjelaskan belanja daerah Kabupaten/Kota di Provinsi Aceh sebesar $94,22 \%$, sedangkan sisanya $(5,78 \%)$ dijelaskan oleh faktor-faktor lain yang tidak dianalisis dalam penelitian ini.

\section{Uji F}

Berdasarkan Tabel 5.6, nilai F-statistik sebesar 747.1787 dan nilai tersebut tergolong signifikan secara statistik di level 1\%. Dengan Kata lain, PAD, DAU, DAK dan OTSUS secara bersama-sama berpengaruh signifikan terhadap belanja daerah pada Kabupaten/Kota di Provinsi Aceh.

\section{Pembahasan \\ Pengaruh PAD terhadap Belanja Daerah}

Berdasarkan hasil analisis data yang telah dilakukan, ditemukan bahwa PAD berpengaruh positif dan signifikan terhadap belanja daerah kabupaten/kota di Provinsi Aceh. Koefisien regresi PAD sebesar 0.0372, yang menunjukkan bahwa ketika PAD naik 1\%, maka belanja daerah akan meningkat sebesar $0.0372 \%$ dengan asumsi DAU, DAK dan OTSUS tetap. Ini membuktikan bahwa naiknya PAD akan berdampak pada kenaikan belanja daerah. Selain itu, hasil penelitian ini juga membuktikan bahwa PAD menjadi prediktor dalam meningkatkan belanja daerah. Hal ini sejalan dengan beberapa studi sebelumnya, seperti Mawarini et al., (2013), Magowan (2013), Mulyati \& Yusriadi (2017) serta Syamni \& Ichsan (2018) yang menemukan bahwa PAD berpengaruh positif dan 
signifikan terhadap belanja daerah. Jika dibandingkan dengan kajian Syamni \& Ichsan (2018), penelitian ini memiliki nilai koefisien yang lebih rendah. Hal ini menunjukkan bahwa pengaruh PAD terhadap Belanja Daerah di Kabupaten/Kota yang ada di Provinsi Aceh menjadi semakin menurun.

PAD memberikan pengaruh positif dan signifikan terhadap belanja daerah, dimana pemerintah daerah dituntut untuk bisa mengembangkan dan meningkatkan PAD dengan memaksimalkan sumber daya yang dimiliki agar mampu membiayai segala kegiatan penciptaan infrastruktur dengan pengalokasian belanja daerah (Wandira, 2013). Pendapatan asli daerah yang diperoleh dari pajak daerah, retribusi daerah, laba BUMD dan lain-lain PAD yang sah mampu memberikan dampak baik pada tingkat investasi daerah. Optimalisasi PAD akan mampu digunakan untuk membiayai pengeluaran dan belanja daerah, sehingga daerah lebih mandiri dan tidak tergantung dengan dana transfer pusat. Dengan begitu, peningkatan invetasi modal diharapkan juga mampu meningkatkan kualitas publik dan pada gilirannya mampu meningkatkan tingkat partisapasi publik terhadap pembangunan yang tercermin dari adanya peningkatan PAD (Palealu, 2013). Hal ini sejalan dengan yang ditemukan oleh Syamni \& Ichsan (2018) dimana PAD memberikan pengaruh positif terhadap belanja daerah.

Daerah yang memiliki PAD yang tinggi tentunya daerah yang mandiri dan mampu memanfaatkan potensinya untuk menambah kas daerah. Dalam hal tersebut, dibutuhkan belanja daerah untuk mengembangkan potensi-potensi daerah tersebut, sehingga anggaran belanaja daerah tentunya meningkat, dimana belanja daerah dapat dikucurkan pada aspek penigkatan infrastruktur dalam kaitannya dengan PAD. Lestari et al. (2016) berpendapat bahwa PAD yang tinggi menyebabkan daerah tersebut menjadi mandiri sehingga kegiatan balanja daerah yang dikucurkan dapat optimal. Ini sejalan dengan yang ditemukan oleh Mawarini et al., (2013), dimana belanja daerah akan meningkat pada saat PAD daerah tersebut tinggi.

Secara teoritis, PAD yang tinggi akan digunakan pemerintah dalam meningkatkan kesejahteraan rakyat. PAD akan digunakan untuk untuk mengembangkan potensi-potensi daerah, dimana pengeluaran tersebut tergolong dalam pengeluaran modal yang termaksud dalam belanja daerah. Ini menunjukkan bahwa suatu daerah harus mengoptimalkan unsur-unsur yang dapat dijadikan sebagai sumber PAD. Sebagai contoh pajak daerah, pihak pemerintah daerah dapat mengontrol dan mengendalikan pajak daerah agar masuk ke daerah secara optimal. Kemudian melakukan sistem yang tepat dalam mengelola distribusi daerah, agar distribusi tersebut tidak diselewengkan oleh pihak-pihak yang tidak bertanggung jawab. Selanjutnya, pihak pemerintah daerah harus memperhatikan kinerja BUMD nya agar terus meningkat yang dapat dilakukan dengan evaluasi kinerja BUMD dan rekrutmen yang tepat agar kinerjanya meningkat. Pengoptimalisasian komponen-komponen PAD tersebut akan mampu menambah kas daerah, sehingga kucuran dana untuk belanja daerah dapat digunakan untuk infrastruktur dan kesejahteraan rakyat.

\section{Pengaruh DAU terhadap Belanja Daerah}

Berdasarkan hasil analisis data yang telah dilakukan, ditemukan bahwa DAU berpengaruh positif dan signifikan terhadap belanja daerah pada Kabupaten/Kota di Provinsi Aceh. Koefisien regresi DAU sebesar 0.7373 yang artinya ketika DAU nai 1\%, maka belanja daerah meningkat sebesar $0.7373 \%$, dengan asumsi PAD, DAK dan OTSUS konstan. Dengan kata lain, kenaikan DAU akan berdampak signifikan pada kenaikan belanja daerah. Selain itu, penelitian ini juga memberikan implikasi bahwa DAU dapat menjadi prediktor dalam meningkatkan belanja daerah. Hasil ini mendukung beberapa studi sebelumnya, seperti studi yang dilakukan oleh Ernaya (2017), Rasyid (2018) dan Syamni \& Ichsan (2018) yang menemukan bahwasa DAU berpengaruh positif dan signifikan terhadap belanja daerah. Jika berkaca pada riset Syamni \& Ichsan (2018) yang menemukan parameter DAU terhadap belanja daerah sebesar 1.5376, maka riset yang penulis lakukan menemukan bahwa terjadi penurunan pengaruh DAU terhadap belanja daerah di Provinsi Aceh.

Penelitian ini membuktikan bahwa DAU dapat menjadi alat yang dapat meningkatkan belanja daerah. DAU sendiri merupakan jenis transfer dana antar tingkat pemerintahan yang tidak terikat dengan program pengeluaran tertentu (Awaniz, 2011). DAU memiliki fungsi untuk menutup celah yang terjadi karena kebutuhan daerah melebihi yang melebihi potensinya (Ferdiansyah et al., 2018). Adanya DAU menjadi penyerahan kewenangan pemerintah pusat kepada pemerintah daerah, dimana hal tersebut membuat pemerintah daerah leluasa dapat menggunakan DAU dalam memberi pelayanan yang lebih baik kepada masyarakat dan dapat diwujudkan dengan optimalisasi belanja daerah (Hapid et al., 2015; Hairiyah et al., 
2017). Uraian tersebut sejalan dengan temuan Syamni \& Ichsan (2018) yang menemukan bahwa DAU menjadi faktor yang dapat meningkatkan belanja daerah di Aceh.

DAU memberikan dampak pada peningkatan belanja daerah (Rasyid, 2018). DAU yang tinggi menunjukkan bahwa daerah tersebut memiliki desntralisasi fiskan yang baik, sehingga diharapkan dapat meningkatkan kesejahteraan publik melalui pengeluaran daerah (dalam hal ini belanja daerah) (Lestari et al. 2016). Ini sejalan dengan yang ditemukan oleh Ernaya (2017), dimana kenaikan DAU akan memberikan dampak baik pada belanja daerah.

Penggunaan DAU diserahkan kepada daerah sesuai dengan prioritas dan kebutuhan daerah untuk peningkatan pelayanan kepada masyarakat dalam rangka pelaksanaan otonomi daerah. Pada umumnya, DAU banyak digunakan untuk membayar gaji pegawai daerah. Belanja pegawai sendiri tergolong dalam langsung daerah. Tingginya kucuran belanja pegawai yang diberikan daerah membuat pelayanan daerah dan pekerjaan-pekerjaan rumah daerah dapat diselesaikan dengan efektif dan efisien. Hal ini membuat proyek-proyek daerah yang dijalankan oleh pegawai dapat optimal dan mampu menigkatkan belanja daerah. Uraian tersebut menunjukkan bahwa DAU memberikan dampak positif dan signifikan terhadap belanja daerah.

\section{Pengaruh DAK terhadap Belanja Daerah}

Berdasarkan hasil analisis data yang telah dilakukan, ditemukan bahwa DAK berpengaruh positif dan signifikan terhadap belanja daerah pada Kabupaten/Kota di Provinsi Aceh. Koefisien regresi DAK sebesar 0.2154, yang menunjukkan bahwa ketika DAK naik 1\%, maka belanja daerah akan meningkat sebesar 0.2154 dengan asumsi PAD, DAU dan OTSUS konstan. Kenaikan DAK akan berdampak signifikan pada peningkatan belanja daerah di Kabupaten/Kota Provinsi Aceh. Selain itu, hasil ini juga membuktikan bahwa DAK menjadi prediktor peningkat belanja daerah. Hasil ini sejalan dengan temuan beberapa studi sebelunya, seperti Syamni \& Ichsan (2018), Ferdiansyah et al. (2018) dan Salawali et al. (2016) yang menemukan bahwa DAK berpengaruh positif dan signifikan terhadap belanja daerah. Melihat dari nilai koefisien yang ditemukan oleh Syamni \& Ichsan (2018) untuk pengaruh DAK terhadap belanja daerah (1.7017), maka riset ini hanya menemukan nilai koefisien sebesar 0.2154 yang membuktikan bahwa pengaruh DAK terhadap belanja daerah semakin menurun di Provinsi Aceh.

Hasil temuan ini memberikan implikasi bahwa DAK dibutuhkan dalam meningkatkan belanja daerah pada Kabupaten/Kota di Provinsi Aceh. DAK sendiri merupakan bantuan besumber dari APBN yang diberikan untuk suatu daerah tertentu bertujuan untuk mendana kegiatan yang menjadi keperluan daerah dengan mengikuti kebijakan dan program pembangunan nasional berdasarkan UU No 33 Tahun 2004. Pengaruh positif DAK terhadap belanja daerah dapat memberikan penjelasan Dana Alokasi Khusus yang dialokasikan melalui APBN oleh pusat dan diberikan kepada pemda untuk peningkatan keperluan daerah sesuai dengan kebijakan dan program nasional mampu meningkatkan infrastruktur sarana dan prasarana, fasilitas publik melalui peningkatan belanja daerah.

Pemerintah daerah dapat menggunakan DAK untuk memberikan pelayanan kepada publik yang direalisasikan melalui pengeluaran-pengeluaran daerah. DAK diberikan dengan tujuan untuk mebiayai kegiatan-kegiatan khusus pada daerah tertentu yang merupakan urusan daerah dan sesuai dengan prioritas nasional, khususnya membiayai kebutuhan sarana dan prasarana pelayanan dasar masyarakat yang belum mencapai standar tertentu atau mendorong percepatan pembangunan daerah (Hairiyah, 2018). Ini sejalan dengan yang ditemukan oleh Salawali et al. (2016), dimana peningkatan DAK mendorong pada peningkatan belanja daerah.

DAK biasanya digunakan untuk meningkatkan infrastruktur-infrastruktur publik, seperti infrastruktur transportasi, kesehatan, pendidikan dan pelayanan daerah. Hal ini tentunya berkaitan dengan belanja barang dan jasa yang menjadi salah satu komponen belanja langsung daerah. Ketika daerah mendapatkan DAK yang lebih tinggi dari pemerintah pusat, maka pemerintah akan mengeluarkannya pada pos belanja barang dan jasa, sehingga hal tersebut membuat kucuran belanja daerah meningkat. Dengan adanya perencanaan yang baik dari pihak pemerintah daerah, maka DAK akan dapat dioptimalisasikan pada infrastruktur-infrastruktur yang potensial sehingga kesejahteraan rakyat meningkat dengan adanya belanja daerah tersebut.

\section{Pengaruh OTSUS terhadap Belanja Daerah}


Berdasarkan hasil analisis yang telah dilakukan, ditemukan bahwa OTSUS berpengaruh positif dan signifikan terhadap belanja daerah Kabupaten/Kota di Provinsi Aceh. Koefisien OTSUS sebesar 0.0897, artinya ketika OTSUS naik 1\%, maka belanja daerah akan meningkat sebesar 0.0897, dengan asumsi PAD, DAU dan DAK konstan. Ini menunjukkan bahwa semakin tinggi OTSUS, maka belanja daerah Kabupaten/Kota di Provinsi Aceh juga akan meningkat. Hal ini sejalan dengan temuan Anwar et al. (2018), Nufus \& Asmara (2017) serta Jikwa \& Salle (2017) yang menemukan bahwa OTSUS berpengaruh positif dan signifikan terhadpa belanja daerah. Nufus \& Asmara (2017) menemukan bahwa nilai koefisien antara OTSUS dan belanja daerah di Aceh sebesar 0.1282, dimana nilai tersebut lebih tinggi dari pada yang penulis temukan dalam riset ini. Ini menunjukkan bahwa terjadi penurunan pengaruh OTSUS terhadap belanja daerah di Aceh.

Daerah dengan dana OTSUS yang tinggi mendorong daerah tersebut untuk dapat meningkatkan kesejahteraan rakyatnya. Rohim (2014) berpendapat bahwa OTSUS dapat meredam konflik pada suatu daerah dan membuat masyarakat pada daerah tersebut sejahtera. Wijaya (2017) berpendapat bahwa dengan dana OTSUS yang tinggi, daerah dapat meningkatkan kualitas operasioal daerah dengan mengoptimalkannya pada kegiatan investasi dari belanja daerah yang dikeluarkan pada periode tersebut. Musa'ad (2016) berargumen bahwasanya OTSUS dapat membuat eksistensi suatu daerah meningkat, sehingga kegiatan belanja daerah tersebut menjadi lebih mandiri.

OTSUS sendiri merupakan dana yang diberikan oleh pemerintah Indonesia kepada Aceh berdasarkan Nota Kesepahaman Heilsinki di tahun 2005 yang melahirkan Undang-Undang tentang Pemerintah Aceh di tahun 2006. Pada Nota Kesepahaman tersebut, OTSUS diprioritaskan untuk 6 bidang, yaitu pendidikan, kesehatan, kesejahteraan sosial, infrastruktur, ekonomi kerakyatan, dan keistimewaan Aceh. Kebijakan-kebijakan dan rencana yang tepat seharusnya dilakukan oleh pihak pemerintah daerah Aceh untuk dapat memanfaatkan OTSUS sebaik mungkin, sehingga ketika OTSUS berakhir (tahun 2027), Aceh dapat menjadi daerah yang maju dan mandiri. Langkah yang dapat diambil seperti menyerahkan proyek kepada bisnis (tidak hanya kepada SKPA saja) agar hubungannya bisa business to businee, bukan orientasi kepada fee proyek. Selanjutnya, dana OTSUS juga bisa digunakan untuk mendirikan BUMD-BUMD agar nantinya ketika OTSUS berakhir, Aceh dapat menjadi semakin mandiri.

\section{KESIMPULAN DAN SARAN Kesimpulan}

Berdasarkan hasil penelitain yang telah dilakukan, maka kesimpulan yang dapat diambil dari penelitian ini adalah sebagai berikut:

1. PAD berpengaruh positif dan signifikan terhadap belanja daerah pada Kabupaten/Kota di Provinsi Aceh.

2. DAU berpengaruh positif dan signifikan terhadap belanja daerah pada Kabupaten/Kota di Provinsi Aceh.

3. DAK berpengaruh positif dan signifikan terhadap belanja daerah pada Kabupaten/Kota di Provinsi Aceh.

4. OTSUS berpengaruh positif dan signifikan terhadpa belanja daerah pada Kabupaten/Kota di Provinsi Aceh.

\section{Saran} berikut:

Berdasarkan hasil kesimpulan di atas, maka saran yang dapat penulis berikan adalah sebagai

1. PAD berpengaruh positif terhadap belanja daerah, sehingga disarankan kepada pihak pemerintah daerah pada Kabupaten/Kota di Provinsi Aceh dapat mengoptimalkan potensi daerah untuk meningkatkan PAD dilakukan dengan optimalisasi pajak daerah, retribusi daerah, laba BUMD dan sumber-sumber PAD lain yang sah, yaitu dengan cara mengontrol dan menciptakan sistem yang mutakhir dalam memungut pajak dan retribusi daerah, mengembangkan kinerja BUMN, serta melihat potensi-potensi daerah di Aceh, khususnya pembangunan wisata syariah di Aceh.

2. DAU berpengaruh positif dan signifikan terhadap belanja daerah, sehingga disarankan kepada pihak pemerintah daerah pada pada Kabupaten/Kota di Provinsi Aceh untuk menggunakan DAU sebaik- 
baiknya, tidak hanya pada belanja operasional saja (seperti belanja pegawai), tetapi sebaiknya digunakan untuk pembangunan daerah, karena DAU diberikan pemerintah pusat untuk pembangunan daerah.

3. DAK berpengaruh positif dan signifikan terhadap belanja daerah, sehingga disarankan kepada pihak pemerintah daerah pada Kabupaten/Kota di Provinsi Aceh untuk mengendalikan dan menggunakan DAK, yaitu dengan melakukan penganggaran yang akuntabel dan transparantif, dan penggunaan DAU juga harus disertai dengan perencanaan daerah demi terciptanya kesejahteraan daerah.

4. OTSUS berpengaruh positif dan signifikan terhadap belanja daerah, sehingga disarankan kepada pihak pemerintah daerah pada Kabupaten/Kota di Provinsi Aceh untuk mengoptimalkan penggunaan OTSUS dalam mensejahterakan masyarakat Aceh, seperti dengan menciptakan BUMD baru agar Aceh dapat terus berkembang setelah berakhirnya OTSUS.

\section{DAFTAR REFERENSI}

Anwar, A. R. D., Abdullah, M. F., \& Hadi, S. (2018). Analisis Pengaruh Pendapatan Asli Daerah, Dana Otonomi Khusus dan PDRB Terhadap Belanja Daerah Di Kab/Kota Provinsi Papua. Jurnal Ilmu EKonomi JIE, 2(1), 1-13.

Asmara, J. A. (2017). Pengaruh Pendapatan Sendiri dan Dana Perimbangan terhadap Belanja Modal dengan Dana Otonomi Khusus sebagai Pemoderasi pada Kab/kota di Provinsi Aceh. Jurnal Ilmiah Mahasiswa Ekonomi Akuntansi Unsyiah, 2(3), 1-9.

Awaniz, Berlian Nur. (2011). Pengaruh Dana Alokasi Umum (DAU) dan Pendapatan Asli Daerah (PAD) Terhadap Belanja Daerah di Eks Karesidenan Pekalongan. Jurnal Keuangan Daerah. Vol 1. No 2.

Darise, Nurlan. (2009). Pengelolaan Keuangan Daerah. Indeks, Jakarta.

Dewi, Ni Wayan Ratna dan I Dewa Gede Dharma Suputra. (2017). Pengaruh Pendapatan Asli Daerah, Dana Alokasi Umum, Dana Alokasi Khusus dan Belanja Modal Terhadap Pertumbuhan Ekonomi. E-Jurnal Akuntansi Universitas Udayana. Vol 18, No 3.

Ernayani, R. (2017). Pengaruh Pendapatan Asli Daerah, Dana Alokasi Umum, Dana Alokasi Khusus dan Dana Bagi Hasil terhadap Belanja Daerah (Studi Kasus pada 14 Kabupaten/Kota di Provinsi Kalimantan Timur Periode 2009-2013). JSHP: Jurnal Sosial Humaniora dan Pendidikan, 1(1), 43-52.

Erlina, dkk, (2012). Pengelolaan dan Akuntansi Keuangan Daerah. USU Press, Medan.

Fajar, Nugroho, dan Abdul Rohman. (2012). Pengaruh Belanja Modal Terhadap Pertumbuhan Kinerja Keuangan Daerah Dengan Pendapatan Asli Daerah Sebagai Variabel Intervening (Studi Kasus di Propinsi Jawa Tengah). Diponegoro Journal Of Accounting. Vol 1, No 2.

Ferdiansyah, I., Deviyanti, D. R., \& Pattisahusiwa, S. (2018). Pengaruh pendapatan asli daerah, dana alokasi umum, dana alokasi khusus, dan dana perimbangan terhadap belanja daerah. INOVASI, 14(1), 44-52.

Fajri, Ahmad. (2016). Pengaruh belanja modal terhadap pertumbuhan ekonomi provinsi-provinsi di Sumatera. E-Jurnal Perspektif Ekonomi dan Pembangunan Daerah. Vol. 5, No. 1.

Ghozali, Imam. (2011). Aplikasi Analisis Multivariate dengan Program IBM SPSS 19. Edisi Kelima. Badan Penelitian UNDIP, Semarang.

Gujarati, Domador N dan Dawn C Porter. (2009). Dasar-Dasar Ekonometrika. Salemba Empat, Jakarta.

Halim, Abdul. (2007). Akuntansi Sektor Publik Akuntansi Keuangan Daerah. Salemba Empat, Jakarta.

Halim, A \& Mujib. (2009). Problem Desentralisasi dan Perimbangan Keuangan Pemerintahan Pusat dan Daerah. Yogyakarta: UGM.

Hairiyah, H., Malisan, L., \& Fakhroni, Z. (2018). Pengaruh dana alokasi umum DAU dana alokasi khusus DAK dan pendapatan asli daerah PAD terhadap belanja modal. KINERJA, 14(2), 85-91.

Hapid, H., Halim, M., \& Wulandari, Y. (2016). Pengaruh Dana Alokasi Khusus, Dana Bagi Hasil dan Dana Alokasi Umum Terhadap Anggaran Pendapatan dan Belanja Daerah Kabupaten Luwu. Jurnal Ekonomi Pembangunan, 2(1).

Indrajaya, I. G. B., \& Sari, R. P. (2014). Pengaruh Dana Perimbangan dan Pendapatan Asli Daerah terhadap Belanja Daerah Kabupaten Badung. E-Jurnal Ekonomi Pembangunan Universitas Udayana, 3(10). 
Jikwa, E., Salle, A., \& Layuk, P. K. A. (2017). Pengaruh Pendapatan Transfer dan Silpa terhadap Belanja Daerah di Kabupaten Mamberamo Tengah. Jurnal Kajian Ekonomi dan Keuangan Daerah, 2(2).

Kusnandar dan Siswantoro, (2012) pengaruh Dana Alokasi Umum, Pendapatan Asli Daerah, Sisa Lebih Pembiayaan Anggaran dan Luas Wilayah terhadap Belanja Modal. Jurnal Universitas Indonesia. Vol 1. No 1.

Koswara E., (2001) Otonomi Daerah Untuk Demokrasi dan kemandirian Rakyat. Yayasan Pariba, Jakarta.

Lestari, A., Dali, N., \& Abdullah, M. (2017). Pengaruh dana alokasi umum (DAU) dan Pendapatan asli daerah (PAD) terhadap Belanja modal dan kemandirian keuangan Daerah provinsi sulawesi tenggara. Jurnal Progres Ekonomi Pembangunan (JPEP), 1(2), 44-55.

Mangowal, J. C. (2013). Pendapatan Daerah Pengaruhnya Terhadap Belanja Modal Pada Pemerintah Provinsi Sulawesi Utara. Jurnal EMBA: Jurnal Riset Ekonomi, Manajemen, Bisnis dan Akuntansi, 1(4).

Mawarni, D., \& Abdullah, S. (2013). Pengaruh Pendapatan Asli Daerah Dan Dana Alokasi Umum Terhadap Belanja Modal Serta Dampaknya Terhadap Pertumbuhan Ekonomi Daerah (Studi Pada Kabupaten dan Kota Di Aceh). Jurnal Akuntansi ISSN, 2302, 0164.

Martunis, M., Darwanis, D., \& Abdullah, S. (2014). Pengaruh Sisa Lebih Perhitungan Anggaran dan Pendapatan Asli Daerah terhadap Belanja Daerah: Analisis Perubahan APBD Kabupaten/Kota se-Aceh. Jurnal Telaah dan Riset Akuntansi, 7(1), 52-57.

Metrika, Jihan. (2014). Analisis Faktor-Faktor Yang Mempengaruhi Pertumbuhan Ekonomi Kabupaten Klaten Tahun 1985-2010. Publikasi Ilmiah Universita Muhammadiah Surakarta.

Mahsun, M., Firma Sulistiyowati, Heribertus Andre Purwanugraha. (2013). Akuntansi Sektor Publik. Yogyakarta : BPFE.

Mardiasmo. (2002). Akuntansi Sektor Publik. Yogyakarta: Andi.

Marytasari, W., \& Soebagiyo, D. (2019). Analisis Belanja Daerah dan Faktor-Faktor yang Mempengaruhi di Indonesia Tahun 2010-2017 (Doctoral dissertation, Universitas Muhammadiyah Surakarta).

Mulyati, S., \& Yusriadi, Y. (2017). Dana bagi hasil dan dana alokasi umum terhadap belanja daerah pada Provinsi Aceh. AGREGAT: Jurnal Ekonomi dan Bisnis, 1(2), 211-220.

Musa'ad, M. A. (2016). Kontekstualisasi Pelaksanaan Otonomi Khusus di Provinsi Papua: Perspektif Struktur dan Kewenangan Pemerintahan. Kajian, 16(2), 357-385.

Nailufar, F., \& Sufitrayati, S. (2019). Pengaruh Pendapatan Asli Daerah dan Dana Alokasi Khusus terhadap Belanja Daerah di Kota Banda Aceh. Jurnal Samudra Ekonomi dan Bisnis, 10(1).

Pelealu, A. M. (2013). Pengaruh dana alokasi khusus (DAK), dan pendapatan asli daerah (PAD) terhadap belanja modal pemerintah kota Manado tahun 2003-2012. Jurnal EMBA: Jurnal Riset Ekonomi, Manajemen, Bisnis dan Akuntansi, 1(4).

Putra, I. B. D., \& Dwirandra, A. A. N. B. (2015). Dana alokasi umum, dana bagi hasil, dana alokasi khusus dan pendapatan asli daerah Provinsi Bali. E-Jurnal Akuntansi, 811-827.

Peraturan Pemerintah No 58 Tahun 2005 tentang Pengelolaan dan Pertanggungjawaban Keuangan Daerah

Putri, Phany Ineke. (2014). Pengaruh Investasi, Tenaga Kerja, Belanja Modal, dan Infrastruktur Terhadap Pertumbuhan Ekonomi Pulau Jawa. Journal of Economics and Policy. Vol 7, No 2.

Rasyid, M. (2017). Pengaruh Dana Alokasi Umum, Dana Alokasi Khusus, Dana Bagi Hasil dan Pendapatan Asli Daerah terhadap Belanja Daerah Kabupaten/Kota Provinsi Sulawesi Tengah. Jurnal Ekonomi Pembangunan. Vol 2. No 1 .

Rohim, N. (2014). Optimalisasi Otonomi Khusus Papua dalam Peningkatan Kesadaran Hukum Masyarakat Guna Meredam Konflik dan Kekerasan. Jurnal Fiat Justisia, 8(1), 80-97.

Sarwono, Jonathan. (2016). Prosedur-Prosedur Analisis Popules Aplikasi Riset Skripsi dan Tesis dengan Eviews. Gava Media, Yogyakarta.

Salawali, W. A., Kindangen, P., \& Lapian, A. C. (2016). Flypaper Effect pada Dana Alokasi Umum (DAU) dan Pendapatan Asli Daerah (PAD) Serta Pengaruhnya terhadap Belanja Daerah Kabupaten/kota di Sulawesi Tengah. Jurnal Pembangunan Ekonomi Dan Keuangan Daerah, 18(2). 
Setyowati. F. (2013). Pengaruh PAD, DAU dan DAK terhadap belanja daerah dengan DBH sebagai variabel Moderasi di Provinsi Jawa Timur. Jurnal Akuntansi Sektor Publik. 3(1).

Simanjuntak, L., Subeki, A., Ferina, I. S., \& Yusrianti, H. (2013). Analysis of Flypapaer Effect in General Allocation Fund and Regional Original Income to Regional Expenditure of Districts and Cities in South Sumatera. Jurnal Akuntansi Publik. Vol 1. No 2.

Sofiyanda, D. \& Ikhsan, M. (2014). Pengaruh PAD, DAU, dan DAK terhadap pengeluaran belanja daerah dengan DBH sebagai variabel moderator. (Studi Empiris pada Kabupaten/Kota di Provinsi Jambi). Jurnal Ekonomi Pembangunan dan Kebijakan Publik. 2(1).

Sharma, S., Durand, R. M., \& Gur-Arie, O. (1981). Identification and analysis of moderator variables. Journal of marketing research, 18(3), 291-300.

Sugiyanta. (2016). Analisis Belanja Modal dan Faktor-Faktor yang Mempengaruhinya Pada Pemerintah Kabupaten/Kota di Indonesia. Jurnal Akuntansi Universitas Jember. Vol. 14, No. 1.

Sugiyono. (2016). Metode Penelitian Kuantitatif, Kualitatif dan R\&D. Bandung: Alfabeta.

Syamni, G. (2018). The Determinants of Districts/Cities Spending in Aceh Province: An Analysis of Electoral Districts. The Journal of Social Sciences Research, 295-298.

Tahar, Afrizal dan Maulida Zakhiya. (2011). Pengaruh Pendapatan Asli Daerah dan Dana Alokasi Umum Terhadap Kemandirian Daerah dan Pertumbuhan Ekonomi Daerah. Jurnal Akuntansi dan Investasi. Vol. 12, No. 1.

Untung, J. (2015). Pengaruh Pendapatan Asli Daerah, Dana Alokasi Umum, Dana Alokasi Khusus, terhadap Belanja Daerah dan Dana Bagi Hasil sebagai Pemoderasi Pemerintah Kabupaten/Kota di Provinsi Jawa Barat Periode Tahun 2010/2014. E-Journal Widya Ekonomika, 1(1).

Undang-Undang Republik Indonesia No. 32 tahun 2004 tentang Pemerintahan Daerah.

Wandira, A. G. (2013). Pengaruh PAD, DAU, DAK, dan DBH terhadap pengalokasian belanja modal. Accounting Analysis Journal, 2(1).

Wibowo, D. \& Syafri. I. (2010). Peran DBH dalam memoderasi pengaruh PAD, DAU dan DAK terhadap belanja daerah pada Provinsi Jawa Barat. Jurnal EMBA. 2(1).

Widarjono, A. (2013). Ekonometrika. UPP STIM YKPN. Yogyakarta.

Wijaya, A. H. C. (2017). Kajian Pengelolaan Dana Otonomi Khusus di Kabupaten Asmat. Jurnal Kajian Ekonomi dan Keuangan Daerah, 1(1). 